\title{
The Social Imaginaries Sociologies: the beginning of a needed conceptual clarification
}

\author{
Las Sociologías de los Imaginarios Sociales: el comienzo de una necesaria \\ clarificación conceptual
}

\section{MANUEL TORRES CUBEIRO \& ÁNGEL ENRIQUE CARRETERO}

\begin{abstract}
This article clarifies the concept of social imaginary, an increasing popular term within social sciences and humanities. It opens with an analysis of the different notions of social imaginary by Durand and Castoriadis to address then the idea of social imaginary by Taylor. Finally, the concept of social imaginaries -now in plural- by Pintos centers our attention. The article offers an analysis of the similarities and differences among these four schools of the imaginary. It clarifies how social imaginaries differ from the concept of social representation and the idea of social belief. We describe also the potentialities of asocial imaginaries sociology for the analysis of social reality and ends pointing to the possibilities that the future opens to the social imaginaries' perspectives, taking in account their probable convergences and disparities.
\end{abstract}

Key Words: Social imaginary, social imaginaries, Durand, Castoriadis, Taylor, Pintos.

Resumen: Este artículo aclara el concepto de imaginario social, un término cada vez popular dentro de las ciencias sociales y las humanidades. Se abre con un análisis de las diferentes nociones de imaginario social de Durand y Castoriadis, para luego abordar la idea de imaginario social de Taylor. Finalmente, centra su atención en el concepto de imaginarios sociales -ahora en plural- de Pintos. El artículo ofrece un análisis de las similitudes y diferencias entre estas cuatro escuelas del imaginario. Aclara cómo los imaginarios sociales difieren del concepto de representación social y de la idea de

\footnotetext{
* Profesor Asociado, Departamento de Filosofía y Antropología, Universidad de Santiago de Compostela, Santiago de Compostela, España. Código ORCID: org/0000-0003-3764-6262. Contacto: manueltorres.cubeiro@usc.es

* Profesor Asociado, Departamento de Filosofía y Antropología, Universidad de Santiago de Compostela, Santiago de Compostela, España. Miembro de la Red Iberoamericana de Investigación en imaginarios y Representaciones. Código ORCID: org/0000-0002-2498-1291 Contacto: angelenrique.carretero@usc.es
} 
creencia social. También describe las potencialidades de la sociología de los imaginarios sociales para el análisis de la realidad social y, finalmente, apunta las posibilidades que el futuro abre a las perspectivas de los imaginarios sociales, teniendo en cuenta sus probables convergencias y disparidades.

Palabras Clave: Imaginario social, imaginarios sociales, Durand, Castoriadis, Taylor, Pintos.

\section{Introduction: A Needed Clarification}

$\mathrm{D}$ uring the last two decades of $20^{\text {th }}$ century the notion of social imaginary (SI) emerged amid the field of humanities and social sciences. Previously, the term had been frequently used in philosophy, but without the sociological precision that would be desirable. At the beginning of $21^{\text {st }}$ century, the appearance of this notion has caused a usage with a nonconsensual meaning in areas such as sociology (Ch. Taylor), anthropology (G. Durand, C. Castoriadis and later M. Maffesoli) and studies linked to communication (J. L. Pintos). Unfortunately, there is not a unique meaning for this concept but a somehow swampy territory. The aim of this article is far from draining such swamp but to contribute to start some conceptual clarification. Mainly, because the rough use of the notion risks of becoming an undefined space in social analysts. Such danger could be prevented if the concept itself undertakes a theoretical elucidation.

In this direction, this article provides steps to begin such conceptual clearance. Firstly, this paper will distinguish between the two more influential SI schools in Franceshowing the reasons for their disagreement: one school inspired by Durand and latter headed by Maffesoli; and a second school founded by Castoriadis. Secondly, the paper presents an explanation of the theoretical boundaries between such close ideas as "social representation" and "social belief". Both notions have been frequently close in meaning to the concept of SI. Our intention is to prevent further ambiguities. Thirdly, we address a short description of the idea of SI by the Canadian scholar Taylor. Finally, the paper reviews the concept of SI by the Spanish scholar Pintos. Both Taylor and Pintos will allow us to finish this essay with a few notes on the similarities and differences between the different SI schools presented here. Because as we will soon see, the SI theories were born in an intellectual background to fight against the perceived excesses of positivism; and to defend subjectivity and religiosity as the core from where any social institution eventually emerges, takes form and proclaims its legitimacy. 


\section{The French Conection: The imaginary matrix as the defense against positivism}

$\mathrm{T}$ The French scholars Durand and Castoriadis started to use the notion of SI within the intellectual environment of the first half of the $20^{\text {th }}$ century. Authors such as E. Cassirer (1955), G. Bachelard (1987), C. G. Jung (1991), H. Corbin (1993) and E. Durkheim (1965) among othersconverged during that period to a similar epistemological inclination that could be condensed into three points. A first common characteristic of these authors can be found in a shared approach to what they define as knowledge. Because these influenced authors followed alternative paths to the rationalism installed then as the basic identity of what was considered knowledge in western societies. They all shared a rejection of the pure theoretical, conceptual and intellectual perspectives of that time: they defended instead a more experiential approach. Finally, these writers had in common a revival of the romanticism, a romanticism linked to the protection of imagination. An imagination understood as a "nocturnal regime" or the Dionysian element hidden in social life.

This background starving for a non-rationalist, more experiential and imaginative perspective would blossom in different forms. A good example was the Collège de Sociologie. Durkheim inspired the heterodox school Collège de Sociologie, where R.Callois, G. Bataille and M. Leiris worked (Bataille-Hollier, 1988). This school generated a line of research that became known as The Sociology of the Sacred. The Collège de Sociologie rediscovered the religious ingredient that survived within modern secular societies. Their research showed a religious ingredient embedded in many modern community manifestations surfacing contemporaneity.

In this intellectual context, a climate of dissatisfaction with the positivism guided French progressive scholars towards the need to overcome the predominant positivist epistemological dogma. The concept of SI would emerge in this line of work within this academic background that gave light to the notion "scientific paradigm" by Th. S. Kuhn (2012), or the concept of "episteme" developed by M. Foucault (1970) among others. The idea was to rethink the social conditions of possibility that generate knowledge, to express it in a Kantian mode. Somehow the idea projected to draw the lines of an aprioristic horizon in which science became socially framed. This intellectual atmosphere prefigured what later became the so-called "French sociology of the imaginary" (see for further detail P. Tacussel 2000, p. 117-25).

One first common aspect to this French sociology of the imaginary places its birth in a post-empiricist origin. This post positivism philosophy positioned our French scholars to understand how social facts emerged from a social nursery surrounded by social beliefs, collective representations and symbolic systems. The sociology of the imaginary was born far from pretending to be just one more subject among other sociological subspecialties such as family, work or education sub-fields. 
A second common feature of this sociology of the imaginary lays on a double view enclosed in the notion of SI. On the one hand, the social imaginary is instituting. Social imaginary is in this sense understood as a creative power from which emerges any in development cultural form. The SI explains social creativity of new social forms. On the other hand, the SI is already instituted. It is understood then as the source of social meanings previously embodied in social institutions. The SI has an acquired solidity, given that the SI legitimizes the social established reality.

Another common intention of this French sociology of the imaginary was to become a knowledge of the depths, analogous to the pretended task carried out on individual psychology by psychoanalysis. In this sense, the SI reveals the implicit social meanings on which the substance of a collectivity is predetermined. This French sociology privileges an analysis of the objectified meaning of social action, exploring then the processes in which meaning is collectively generated.

A final common feature is that this French sociology underlines explicitly that the social imaginary is translated in social meaning thanks to socially created symbols. Because symbols mediate between the real and the imaginary, the material and the immaterial, the determined and the undetermined. After shortly describing the main features of the intellectual background, it is time to approach the two main schools of the SI in France: that of Durand and, that other created by Castoriadis

\section{Durand: The imaginative social matrix}

".. the great semantics of the imaginary is the original matrix from which all the rationalized thought and its semiological follow-up develop. Therefore, we definitely want to place ourselves in the symbolic perspective to study the fundamental archetypes of the human imagination" (Durand 1960, p. 27)*.

In the intellectual background described, Durand's first work of 1962 (1999) was entitled: Anthropological Structures of the Imaginary. Durand's book has not only socio-anthropological aspirations but also consequences for the whole field of scientific knowledge (Thomas, 1998). This is the case, because Durand pretended with his analysis to reflect the intellective power housed within the image and the imagination (Fleury, 2006). In short, Durand guidelines could be summarized in three main features. First, Durand presents in his work a clear uneasiness against rationalism. He sees rationalism as the hyperbolic path that dominates the West intellectual world. Hence, Durand defends the need to readmit a "nocturnal regime" of the imaginary. In consequence, any investigation in social science must accept the double anthropological nature of any human endeavor: simultaneously rational and non-rational.

A second characteristic of Durand's approach is that he would defend a reencounter with certain archetypal images. Archetypical images assumed as primordial 
and foundational in any given cultural heritage. Durand accepts these archetypical images as a background constituted by anthropological constants. Such imagines will take shape in a repertoire of perennial mythological figures. And this leads us to the third feature of the perspective adopted by Durand in his book. He proclaims that such primordial images have been present eventually in any historical moment. So, the oldest images would be operating in the newest one; the one image in the multiple one: such imaginary background has somehow survived thanks to its versatility. Coherently, Durand's work bets on symbolic hermeneutics as a methodological access to understand any cultural or social manifestation as related to those archetypal images; given that this social imaginary soil will appear materially eventually embodied in any symbol.

Durand theories inspirited the group of scholars known as the School of Grenoble: Maffesoli (1995), Tacussel (2000), A. Pessin (2001) and P. Sansot (1986) among others. Durand's successors adopted an approach with less anthropological emphasis driving their investigations towards a more sociological style. The influence of such scholars has been enormous. They purposed to unveil the archetypal and mythical trace described in Durand's work. These scholars have described how that archetypical background somehow is constantly reincorporated into everyday life. The focus of their sociology stimulates the rediscovery of most immemorial and original permanently latent in the present.

This perspective is coherence with the intellectual background we described earlier, given that Durand's legacy entails a departure from the rationalist discourse that, gestated in the heat of enlightened modernity. Such enlightened modernity defended a simplified vision about religion and myth; seeing them just as systems of representation that would be eventually reprobated and overcome by reason. The school of Grenoble following Durand's heritage would search a final goal based on the rediscovery of these sence of modern reason as a myth among many competing mythologies. In consequence, Durand and the school of Grenoble propose a revalorization of the noosphere (Morin 1992, p. 109-132) in our current culture; both mass culture and, digital culture as well. So that the imaginary field cohabites also in our modern culture with that of reality, complementing reality and vivifying reality. This is the case because any human manifestation, even the more technological, operates continuously back and forward from the real to the imaginary and, reciprocally, from the imaginary to the real. Durand and his school shared a common worry for the re-discovery of the myth and the sacred sphere within modernity, even the more secularized one (a perspective also defended by Taylor, as we will see later). These scholars show in their research how the modern process of secularization has generated in our days sacralities that appear to be profane. Durand coined the contradictory term to describe them as profane sacralities. But such profane sacralities as the former religious ones emerged from a common archetypical imaginary soil.

Durand's followers shared another common feature: they shared an analysis of what they call micro-imaginaries. With this idea, they aimed to analyze how the sacred has become re-arrange in what Eliade called profane day by day "hierophany" (Eliade 1963). These scholars' defendes the need forum veiling religiosity, mythology and symbolic rituality as acting forces in everyday modern social life. Hence, Maffesoli as 
the most know representative of the Grenoble school points to the "neo-tribalism" as the very manifest verification of the presence of the sacred and the imaginary in our current modern societies (Maffesoli, 1995).

\section{Castoriadis: The social matrix becomes the social magma}

"The institution of society is at every moment the institution of a magma of social imaginary meanings, which we can and should call the world of significations. Hence, each society institutes in each moment a world as the world, and that institutes a world of meanings (...) and only in correlation with such world of meanings, a world can exist" (Castoriadis, 1987, p. 312).

Coherently with the intellectual background described earlier and with Durand's perspective, the title of the most famous book by Castoriadis shows his intentions: The Imaginary Institution of Society (1997). Nevertheless, Castoriadis perspective in this books has some others intellectual roots: first, the young K. Marx (Marx y Engels, 2009); but also the psychoanalysis J. Lacan (1997). Castoriadis elaborates on these sources his notion of imaginary meaning of a society. The quote heading this section of the article points in this direction. According to Castoriadis, what he calls the imaginary meaning of a society configures a globalizing instance that becomes the ground in which each society builds first its identity; but also, the soil on which the totality of the things that compose that society could be considered, could be thought or understood. And in consequence, such imaginary meaning would be the magma on which different social elements could enter in action. In this sense, the imaginary meaning could legitimately be understood as the matrix scheme of society itself. Because this imaginary meaning provides a joint common meaning to the ontological being of any given society; but also, a shared somehow unspoken sense that provides a soil to any given social action.

This notion coined by Castoriadis points even further. The imaginary meaning of a society becomes in his perspective the core pillar that sustains any collective identity. Given that any collective identity could only be maintain using symbols, Castoriadis insists that the true link of any social identity comes before any rational calculus. In coherence with the intellectual background described previously, Castoriadis stands away from rational or positivist visions of society. In this line, Castoriadis vision of social action differs from the view in which self-sufficient individuals voluntarily enter a contractual exchange relationship motivated by obtaining a benefit, which could rationally explain social nature. Far from this rational positivism perspective, Castoriadis requests an ontological description of the social being based on the imaginary. An account that should defend that any given social interchange or interaction stands based on an ontologically pre-conditioned social imaginary. Then, 
according to Castoriadis this imaginary significations influence social manifestations that would be to some extend to its mercy.

Our first step towards the clarification of the SI sociologies has token us to describe the general features of the intellectual endeavor from which the two main French SI schools emerged. Now we need to address the similarities and differences between these two schools of the SI.

\section{Variances in French imaginaries}

Now is time to compare the two French conception of imaginaries we have presented: Durand and Castoriadis. They have points of encounter and points of disagreement. First, we will address the disagreements; because there is an irresolvable non communication between these paradigms that originates from a divergent reading of the notion of social imaginary. We will describe this divergence first to later focus on the similarities between both schools of the imaginary.

Durand's perspective proclaims to be non-political arguing that his perspective focus on anthropological or cultural terms. Durand pretends to find in the past an immemorial knowledge condensed on a mythical and symbolic soil. On an opposite perspective, Castoriadis proclaims his political accent proclaiming an urgent revolution coherent with classical Marxist terms.

A second major divergence between both authors is based on an institutional factor that explains the different impact of both scholars and therefore should not be omitted. The work of Durand has been motivated by the explicit need of creating a school of though. Durand created an institutionalized network in charge of transmitting his legacy, the previously mentioned school of Grenoble. On the other hand, the work of Castoriadis, in contrast to Durand's, has not been driven by this intention. Castoriadis intentions was never to create a school, even when his influence has been quite large.

Although the essential aspect that separates both proposals lay on Durand's understanding of the role to the order of the imaginary. Because Durand thinks that this role lays on fundamentally archetypal terms, a somehow anthropological root that transcends history. Durand understand that this root constitutes the "semantic basins" acting in an underground and recurring way. The deepest cultural background of societies where the influence of C. G. Jung's work is notorious. On contrast, Castoriadis disregards the relevance granted by Durand to this archetypal dimension. Castoriadis perhaps underlines more the emancipatory project of political sign to which he is attached, not seeing that much emancipatory magma on such anthropological basis. The social ontology elaborated by the Greek French philosopher is not intended as an immersion in an anthropological hermeneutic of the deep and latent structures of a culture. Castoriadis limits his clarification to how and why the surrounding world is a historical-social self-institution in based on conventional imaginary meanings; and, how 
only by recognizing the socially self-constituted character of that world, that world could finally be transformed. While Durand's underlines the perennial, Castoriadis' commitment is entirely committed to the transformation of such historical roots.

However, the notions of social imaginary created by Castoriadis, and Durand have also some common features. First, both scholars coincide in their departure from not only the structuralism but also from the semiology that conformed the European intellectual climate during the $20^{\text {th }}$ century sixties and the seventies: specially the anthropological structuralism of the French Cl. Lévi-Strauss (2008) and the semiology of R. Barthes (1972). Castoriadis and Durand both pretended to overcome the rigid formalist framework of structuralism. A structuralism that has seen the human social existence based on latent operative structures wrapped within any social institution. The concept of structure incapacitates social sciences, according to both Durand and Castoriadis. To understand how sense is socially constructed the proclaimed the need to use the imaginary ground that explains societies, far from the grey cold structures.

A second coincidence lies on the rejection of a rationalist vision of the human beings and the social, coherently with what we have described before. Castoriadis and Durand disengage from the unilateral project of modernity based on the triumph of an instrumental rationality based on the deification of the category of progress.

In line with this coincidence, the third point in common is a re-evaluation of what had been defenestrated by rationalism, namely: human being in his very condition of delirious, imaginative and creative beings. Castoriadis and Durand share a common emphasis on fostering a double anthropological facet with sociological resonances. A binary anthropological facade which conceives human beings and their societies as rational instances but at the same time as non-rational or delusional devises. Both writers vindicate, thus, an imaginative condition as the very soil in which the social life is installed.

Finally, we can highlight as a common element in both scholars, the exaltation of a matrix or magma that, nested in human action, is responsible for a never-ending fertility that re-creates the emerging effervescent symbolic-cultural forms. Castoriadis and Durand wished to defend an understanding of liberty as the very core of human original condition. A radical defense of liberty that opposes to any ontological or anthropological vision of a presumably deterministic nature of human beings and their societies.

It is time to enter another field in need of clarification before approaching the perspectives of Taylor about the social imaginary of contemporary society. We need to clarify, as we promise in the introduction of this article, the difference between social imaginary from, first, social representation; and later, from social beliefs. These concepts have a large influence in what we have named the "intellectual swamp" in which social sciences have constructed their theoretical approaches. 


\section{Social imaginaries are not social representations}

The notions of social imaginary and social representation have been frequently used in juxtaposition. Something de facto pointing to a chronic lack of definition on which both Castoriadis and Durand seem to have been contaminated. It is therefore appropriate to attempt here an effort to clarify the differences and similitudes (see Girola, 2007, p. 64). In this context, the social representation, unlike the social imaginary, would have a more limited aspect and a more conventional and prescriptive function.

The notion of social imaginary refers to an instituting (creative) power nested in the background of every society. A force which generates incessantly self-creating unusual cultural forms. This power links intimately to an effervescent ex nihilo creativity inseparable from the social. In this sense, the social imaginary refers to an active creative flow coming from the social imaginary. This never-ending creativity finds its crystallization when cultural forms emerge. The social imaginary is not, as in the case of an image or social representation, a fixed photo; because the social imaginary concept incorporates a vision of society as a never-ending movement based on an archetypical imaginary soil. Social representations point to a more static view of society, while the idea of social imaginary present a more dialectic perspective about the social.

A second difference between social representation and social imaginary is based on what has been called the immaterial treasure of any given culture. In this sense, the notion of SI describes the processes in which any society storages the deposit of immaterial culture treasured in any given time. Then, the SI exceeds the superficial layers of any short living social representation. The SI dives into a more anthropological tectonic deep nature. This SI notion profound nature makes it extremely difficult to think that the SI can be exhausted in a social representation. Due to its anthropological vocation, the essence of the SI points towards deep structures; deep structure that could only be captured from a hermeneutical socio-analysis of the collective (Baeza, 2003; Coca, 2008).

A third significant difference between SI and social representation lays on the relationship with the symbolic layer in any society. The concept of SI describe how society is based on a strong use of the symbolic. From both Castoriadis and Durand perspectives no social representation could reflect such symbolic echoes connatural to the SI they both describe. The SI transfers any people to refer to an enclave of symbolic forms; such forms are the place where the cultural density takes a real seat. Hence, the SI nature surpasses the conventional semiotic-categorical borders, the always concrete signal delimitation where the image/representation is imprisoned. This SI symbolic nature rises beyond any discursive corseted closure. Its symbolic essence appeals to the 
undetermined uncluttered landscape that opens itself to a never-ending emerging content encircled within the symbol.

Fourth, the social imaginary moves in-between a confessed interference with the symbolic-ideational universe sustained inside a mythological kingdom. By contrast, the mythological touch is not present when social representations are in usage. In other words, the SI aspires to declare itself as a global matrix of meaning. Unlike the social representation which is fixed to a specific circumscribed temporal something: a down to earth anchorage in social representation to a given cultural time and special momentum. In contrast, the SI transcends any given social construction of time, because the SI invokes a mythical a-temporal dimension. The SI bumps with the functional essence of the myth. In doing so, this SI mythical nature provides social resources to build up social tools ${ }^{3}$. Utensils that provide the light of a-temporal myths to illuminate current social issues.

After providing some preliminary differences between social representations and social imaginaries, we will now approach its differences with social beliefs.

\section{Social imaginaries are not social beliefs}

We will use in this article the notion of social beliefs referring to collectives believes. The classical distinction created by the Spanish philosopher J. Ortega y Gasset between ideas and beliefs could at this point be handy. The Spanish thinker alleges that ideas are possessed, while in beliefs one stands on (Ortega y Gasset, 1986, p. 23). In this sense, the social imaginary is clearly closer to the Ortega's use of belief, and it would be far from his concept of idea. Then, the social imaginary would be a social tool which allows people to belief and stand on and observe reality. If we apply now what we have said before in the article, then, social beliefs would be the product of the social imaginary.

A second differentiating element between social beliefs and social imaginaries is that the social imaginary would not be circumscribed to any given type of social belief. The SI relates to a collective central type of belief, that credence traditionally defined as religious. The SI links its nature then with a pragmatic centrality gained prior to the modern secularization. This is the case because religion provided meaning for a broad social body during many centuries. Again, the SI would be the primordial anthropological source of any given belief, not just the religious ones. The term belief system(s) would be more accurate here, instead of the social belief. Because the attributed centrality of social beliefs would only be effective if it is firmly assumed without fissures among believers. Belief System should then understand as a corpus and not as it has usually been understood following Levi-Strauss structuralism. Since this corpus is not a conglomeration of formally interdependent elements that, by reason of a relational logic combinatorial, make up an operative unit. 
A fourth issue is that a system of social beliefs collides with the social imaginary not so much in its internal systemic coherence but in an aura of sacredness and inviolability. Because, both systems of social beliefs and the SI converge in adding an immanent transcendence whenever they are in usage. Consequently, both share a unanimous sentiment of approval among those who participate in the System or the SI. This sacred dimension guarantees an imperative obligation to those who observance and adhere to this system or share the SI use. Related to this, pre-industrial pre-modern societies offered a link between the religious and the sacred: a link amalgamated in a space of collective centrality. When modern industrial secularization started the religious experience (and its beliefs systems) was evicted from that centrality, losing progressively such holiness. Nevertheless, this sacred element, social in its very nature, did survive the challenges of modern reason; but it's survival undertook metamorphosed secularized features: that would be the sphere of the SI. Although, this sacred social nature element maintained undamaged its commitment: to provide a solid sense structure surviving any historical-social happening or event. So that, former religious attributions became recycled to be re-appropriated by modern tools. Therefore, the SI describes a current "sacred secularized" intimal related with former religious sacred social beliefs. A social secularized shift that did not give up the social function of religion but just translated its attributions to the SI. The modern almost sacred nature of the ideas of Nation, or Democracy or Progress, or New Technologies would be perfect examples. This offers us the perfect link to address the concept of SI in the Canadian scholar Taylor.

\section{Taylor: The imaginary of contemporary society}

"By social imaginary, I mean something much broader and deeper than the intellectual schemes people may entertain when they think about social reality in a disengaged mode. I am thinking, rather, on the way people imagine their social existence, how they fit together with others, how things go on between them and their fellows, the expectations that are normally met, and the deeper normative notions and images that underlie these expectations... the way people "imagine" their social surroundings, and this is not expressed in theoretical terms, but carried in images, stories and legends... the social imaginary is that it is shared by large groups of people, if not a whole society.... the social imaginary is that common understanding that makes possible common practices and a widely shared sense of legitimacy” (Taylor, 2004, p. 21). 
The Canadian sociologist Taylor publishes in 2004 his book: Modern Social Imaginaries (2004). In this work, Taylor defines the SI as the "common understanding that makes possible common practices and a widely shared sense of legitimacy" (2004, p. 21). Taylor argues, in his sociological perspective, that the social imaginaries of modernity have had three key cultural forms animated by the idea of a moral order based on the mutual benefit of equal participants. These three ideas or forms emerged in traditional agricultural societies to support a common image of coexistence on three assumptions presumed as valid. These assumptions would be according to Taylor the playground in which the social imaginary of modernity will blossom.

The first pre-assumption consisted in the shared expectance of an existing common economy or underlying economic exchanges. A second element according to Taylor would be the emergence of a certain public sphere where the common good is somehow managed, discussed and analyzed. Finally, according to Taylor, a third idea would be an ideal of self-government as a ground for that common order. The two French traditions previously analyzed based their approaches more in Durkheim works, while Taylor's perspective centres his perspective more on the English social contract philosophies. Durand and Castoriadis, with the described differences, departed from the intellectual background in which Durkheim ideas emerged, to define the social imaginary on an anthropological archetypical ground. Taylor uses the same concept, the social imaginary, to describe the roots that allowed social links during the change from traditional to industrial societies. Taylor describes in his book how the three assumptions transformed themselves to create a somehow sacred but secular imaginary in which modern societies popped smoothly up. Taylor's SI resembles the rubricated implicit common agreement among humans that facilitates the rise of civilization and keeps somehow maintaining it (basing his ideas in social contract philosophers such as Th. Hobbes, J. Locke, or J. Rawls). But Taylors describes such social "contract" with features that drive his notion far from the social contract theories.

Thus, the social imaginaries are shared socially images that emerged with the passage from traditional agrarian societies to the nation states of capitalism and post capitalism. While in the French tradition, Durkheim in The Elementary Forms of Religious Life (Durkheim, 1965) had established the religious moral order as the collective representation of society, this perspective underlines a consensus with a more sociological than anthropological soil as the basis for any human community and the explanation to how society shifted from a traditional order to an industrial organization. While the French traditions constructed its perspective of the social imaginary on the Durkheim's sociology, Taylor approach of the social imaginary does the proper, basing his approach on the inspiriting ideas of the social contract. Taylor's goal is to explain Western modernity (even postmodernity) by bridging the gap between reason and faith. Taylor pretends to describe how secularization has not forgotten the religious aspect. Taylor aims as well to include multiculturalism, something relevant in his country Canada where cultural diversity has become part of the cultural agenda. According to Taylor, the social imaginary of modernity, multicultural and not as secular as it has been supposed, contains imaginary elements that helped to give birth to the social order that 
tides society together. Explaining how the supposed secularization of the modern order is based on an imaginary social basis, born in agrarian traditions. A common ground that Castoriadis finds more in the so denominated magma of the collective unconscious; and a common ground that Durand anchored in a human anthropological element that transcends cultures. They all have in common the unpredictable element of the imagination, fighting all of them against the most positivist elements of a descriptive quantitively sociology. Now we address a perspective that centers SSII on communication, that of the Spanish scholar Pintos.

\title{
Pintos: Social imaginaries and communication
}

\author{
"The social imaginaries (1), are being (2), schemes (3), \\ socially constructed (4), that guide (5), our perception (6), allow \\ (7), our explanation (8), make possible (9), our intervention \\ (10), in what in different social systems (11), is had being taken \\ as reality (12)" (Pintos, 2018, p. 3-5) ${ }^{1}$.
}

$\mathrm{T}$ he Spanish sociologist Pintos published his first work on social imaginaries in 1995: Social Imaginaries: the new construction of social reality (1995). A first difference with the previous analyzed positions must be observed immediately: Pintos uses in plural the concept of social imaginary: social imaginaries, not the social imaginary (Torres Cubeiro, 2015). In his definition, plurality, as we shall see, is the key.

Once this is clear, Pintos defines social imaginaries as: socially constructed schemes that guide perception, allow explanations, and make intervention possible. Social imaginaries are, for Pintos, social products emerged from social communication. Communication constitutes the core of society, because society emerged as the devise that increases the survival chances of human groups. This is a clear difference between previous analyzed theories. Pintos assumes not the social contract tradition, neither the anthropological archetypical Durkheim background. Pintos approach of the social imaginaries undertakes the social system theory created by the German sociologist N. Luhmann (see Torres Cubeiro, 2013). Social imaginaries are, defends Pintos, those social devices which build the sense of reality in a society constituted by high complexity.

For Pintos, as for Luhmann, society constitutes itself by communications, not by human individuals' interactions (Luhmann, 2012; Moeller, 2013). In a constant flow of communication, social structures arise to simplify complexity. A good example is how Luhmann described the advent of passionate romantic love coinciding with the emergence of industrial societies and capitalism (1986, 2010). Luhmann describes how the concept of romantic love was then generalized as a social tool. Love is a semantic medium in which the possible (or not) understanding among strangers in new urban industrial environments could increase its chances of communicative success. The image of a passionate loved became accessible to increase the possibilities of mutual 
comprehension in moments in which European societies shifted from agricultural to industrial societies. Far from sexual norms of traditional communities, the new industrial urban environments came to see the emergence of a romantic code for new possible sexual encounters. This love code increased the chances of continuity in time of such now random possible encounters, redefining the rules of new forms of the institution known as the family. The new ideals of romantic love served to offer a code to stick to, to guide communication (or not) in the new urban complex context. Luhmann understands that society is the communication system that simplifies communication with tools such as romantic love. Love's codes make communicative success more likely, given that "the institutionalization of love as passion symbolizes the social differentiation of intimate relationships" (Luhmann, 2010, p. 26). With industrialization, romantic love turns an individual experience into something regulated with social expectations that first literature, and later the film industry, will develop and transmit.

Since the nineteenth century when romantic love appeared at the dawn of industrial capitalism, society has become much more complex. Society became planetary with social systems using contradictory logics in what Luhmann describes as policontexturality (Moeller, 2005, 2013). Polycontexturality (not poli-contextuality) comes from a concept taken from G. Günter to describe a specific aspect of social complexity in our current planetary society (1979). Polycontexturality describes the situation in which multiple codes with contradictory values are valid simultaneously within a society. Contextural (not contextual) represents a fabric composed of fragments of diverse materials integrating a unit. Each social system (economy, education, health...) as an element of society develops essentials parts for the social system, but none of those social systems is the dominant one. There are no vertices, no center, and no periphery, there is contexturality, there is polycontexturality. That is the case because it is impossible to describe today's society, society cannot offer itself a description of its complexity, because each social system only sees what it can see from the perspective of the function it develops. Social imaginaries play a role in that very impossibility.

Social imaginaries are, Pintos defends, the social system response to this complexity and coexistence of contradictory logics. The social imaginaries are far more than simplifying social schemes of complexity (Torres Cubeiro, 2009), even more than generalized means such as love. For Pintos, social imaginaries are schemes offering and generalizing simplifications that allow building stability where stability does not really exist. Social imaginaries allow to act where it seemed impossible any given action. Social imaginaries generate tranquility. This is the core reason why Pintos defends a plural use of the social imaginary, given any society is always in process of becoming something different, offering a never-ending future based on the elements previously existing. Pintos' approach underlines his pretension of forget any ontological reference to analyze what society constructs as communicative devises, and in doing so, Pintos approach explains the conservative and utopic elements that such devises include.

Consequently, Pintos defends that social imaginaries could be detected by analyzing the contradictory discourses existing in social communication (2012). Pintos offers a methodology of sociological analysis built on this concept that 
underlines their plural contradictory character. The sociologist must select, Pintos argues, and collect the contradictory versions existing in the social communication. Pintos has applied his methodology with social imaginaries of the mental health patients by recollecting notions of what means to be a patient from the different schools of psychology working together in units of mental health in Spain (2004). Pintos also applied his methodology to analyze social imaginaries of power during Spanish elections to the parliament (2012) by collecting articles from Spanish newspapers positioned from opposite political perspectives. Once the various versions over the same topic have been collected, the methodology proposed by Pintos focuses on detecting observations one perspective offers of the opposite contradictory positions. Social imaginaries could be detected when the contradictory observations presented repetitively in communication repeat once and again. In the example of mental health patients, a patient's diagnosis could be simultaneously "caused" by a brain imbalance for the a psychiatrist, by a psychological crisis for a psychologist, or by a evil spirit for their parents and be the product of socioeconomic variables for a social worker (Torres Cubeiro, 2012). The four visions coexist in society and the function of the imaginaries is to offer plausible simplifications of this complexity that provide meaning in communication. The methodology offered by Pintos thus detects the social complexity and how the social imaginaries simplify it. Pintos theory and methodology generated a school under the umbrella of the so-called GCEIS: Compostela Group for the Study of Social Imaginaries, with headquarters both in Spain and Chile ${ }^{2}$.

Pintos notion of social imaginaries has in common with those of Taylor, Durand and Castoriadis the explicit desire to account in sociology for social creativity, giving voice to elements not included in an academic sociology of a more positivist nature. A second common element lies in their common intentional openness to nonquantitative methodologies, since all these versions of the social imaginary generated multiple research of mainly qualitative nature: the Grenoble School, Maffesoli' works, or the GCEIS have generated mainly qualitative sociological investigations. A third common element, especially clear in the case of Taylor, is an alternative version to the official thematization of the secularization processes. Maybe inspirited in a nostalgic missing emotion of loss of a longed social order, these perspectives share a common critical reading of the postmodern description of our current society.

However, there are also some differences between the position of Pintos and that of the three sociologies previously described. A first difference is that Pintos places the contradictory plurality as the core feature of society. A second difference should be placed in the intellectual background in which the different notions of the social imaginary germinated. Because while the French schools grow from the anthropology of Durkheim with a Marxist and psychoanalysis influence; and the AngloCanadian notion of Taylor came to light inspired by the theories of the social contract; the concept of Pintos social imaginaries on the contrary emerged from a Spanish reading of German sociologies based on communication (Torres Cubeiro, 2015). Finally, a third difference lies on the methodological vocation of the Pintos proposal, with a less philosophical inclination than those of Castoriadis, Durand or Taylor. 


\section{Conclusions: The future sociology of social imaginaries}

As we have seen, the concept of social imaginary captures the open and never-ending changing nature of society. But although society shifts, society does not transform without maintaining old features: social imaginaries according to Pintos or the social imaginary described by Durand, Castoriadis and Taylor offers the soil for transformation coming from ancient traditional elements, allowing both revolutions and permanence. The social imaginary(s) appeared to underline and describe that very dual nature of society. The sociologies of the imaginary in their different French, AngloCanadian and Hispanic-German versions have searched to offer analysis and tools to account for this very social duality.

In short, a first clear conclusion would be that there is not a univocal version of the social imaginary notion but somehow a familiar resemblance among them: a stress on creativity and imagination more than in imitation when describing social practices (Adams et al., 2015). This stress on creativity has maybe caught up their applicability as an operative notion in sociological terms, producing in some cases an erroneous perception of the social imaginary(s) as somehow conceptual undefined. There have been undoubt fully contributions paddling on the same direction stimulated by a common idea: a joint perceived need for the revitalization, largely underestimated by objectivism, of the imaginaries-not-objective that presents themselves in everyday life. All the analyzed sociological proposes defend the possibilities for the socioanthropological analysis. Thus, the sociology of the social imaginary(s) emphasises how society is dynamic, always ready to emerge and change, to revolt itself.

A second shared element would be a certain methodological uncertainty, as well as a perception of the difficulties of bringing coherently together theory and methodology (except for Pintos and his methodological proposal). Nonetheless, the very idea of social imaginary(s) tolerates the coexistence and complementary versions of the same concept. We must also underline that there are multiple notions of the social imaginary(s) that have not been analyzed here: like that inspired by symbolic hermeneutics (Coca-Matas, 2012) or that other based on readings from phenomenology (Baeza, 2005); both versions of the social imaginary that give greater weight to the symbolic and with their own methodological proposals. Some sophisticated symbolic hermeneutics, still in its promising beginnings, is proposed as a future way to establish a bridge between theory and methodology.

Worth to be mentioned here is the proposal bravely treated in this article of Maffesoli. Maffesoli (1985, p. 79-96) has tried to follow this line, proposing the notion of "formism", debtor of the sociological legacy of G. Simmel. Thus, in his opinion, "form" refers us to the historically invariant, to that archetypal accessible through the symbolic. A symbolic soil which would be recurrently present in a multiplicity of historical and current manifestations. Maffesoli applied this approach to the phenomena of collective aggregation, as a ground where the communitarian tendencies of 
communities are based. In any case, the notions of the social imaginary analyzed within this article have been projected on an essentially qualitative methodology, inspiring multiple paths of empirical investigation.

However, there is a risk. Given the emphasis on constructing a replica to objectivism, the sociology of the social imaginary(s) could derivate into culturalism. A over valuation of cultural elements that could lead this sociology to a final undervaluation or marginalization of the objectivity. This could be the case if the imagination elements become overvaulted; given then to an a priori overlapping of the symbolic elements over the more objective. The best formula to avoid this risk would be to link any social imaginary(s) to the social processes that create it, linking the representational with its social objects. Pintos methodological contributions have navigated in this direction.

A fourth final reflection points to the existence of a certain confusion between two registries of the social imaginary; each register with certain treatments and sociological possibilities. On the one hand, the social imaginary institutive aspect, this is, the social imaginary openness to new imaginary social creations. On the other hand, the social imaginary in its instituted aspect, this is, the social imaginary already embodied social institutions. In the first case, the social imaginary is seen as creator of emerging cultural forms and, therefore, as a catalyst for possible established social realities. An aspect that Pintos plurality of social imaginaries underlines. Therefore, this social imaginary institutive nature opens to the nascent and disruptive-revolutionary condition characteristic of certain social phenomena, revolutionary conditions immanent to any social reality. Still, the second social imaginary element, the instituted social imaginary claims the legitimizer use of the social imaginary. Because any society bases its very natures in an already made crystallized shared imaginary soil. A soil that claims its persistence. Therefore, this dual nature of the social imaginary must lay under the schools we have described. Each one describing the double nature in different complementary ways.

In conclusion, the sociology of social imaginaries or the sociology of the social imaginary offers a rich diversity. It offers analysis of society focused on emphasizing the plurality of that society, an objective reality that cannot objectively described as closed, or definitive. These sociologies of the social imaginaries propose an analyze of this social creativity analyzing it not only with cold objective data defended by positivism, but also approaching the subjectivity and the connection that between subjectivities generates social communication, emphasizing at the same time not only those quantifiable elements but especially those close to emotionality affectivity. Away, therefore, from sociological analyzes inspired by positivism, the sociologies of the social imaginaries that we have been analyzed here underlined individual freedom as the basis of every social institution. Just as positivist sociology seems to serve as a tool for maintaining the status quo, the sociologies of the social imaginaries offer perspectives open to creativity, to hope, to unplanned emerging change. All these elements coined with the adjective imagination within the imaginary social notion. A notion opens to future interesting developments. 


\section{NOTES}

*All quotes are translations to English by the authors. English references are included in the final bibliography when English translations of the original French or German books were available.

1. Pintos original definition of social imaginaries includes these twelve features later clarified one by one in the body of his book.

2. See: The Journal Imagonautas (http://imagonautas.webs.uvigo.gal) and RIIN (https://imaginariosyrepresentaciones.wordpress.com/).

3. This a-temporal nature of the social imaginary should be understood as a socially created feature, always available within the mythical "tool-box". A toolbox that guaranties safety to be used when historical concrete acute issues break once and again. 


\section{Bibliografía}

Adams, S., Smith, J., Blokker, P., Doyle, N. J., y Krummel, J. W. M. (2015). Social Imaginaries, 1(1), 1-7.

Bachelard, G. (1987). On Poetic Imagination and Reverie: Selections from Gaston Bachelard. Washington: Spring Publications.

Baeza, M A. (2003). Imaginarios Sociales: Apuntes para la discusión Teórica y Metodológica. Concepción: Editorial Universidad de Concepción.

Baeza, M A. (2005). Presentación Didáctica de La Teoría Fenomenológica de Imaginarios Sociales. Concepción: Editorial Universidad de Concepción.

Barthes, R., (1972). Mythologies. Traducción Annette Lavers. Nueva York: Hill and Wang, 302-306.

Bataille, G., y Hollier, D. (1988). The College of Sociology (1937-39). Minneapolis: University of Minnesota Press.

Carretero Pasín, Á. E. (2010). Para una Metodología de las representaciones Sociales: Una lectura de sus implicaciones epistemológicas. Bogotá: Revista de Metodología de Ciencias Sociales, 20, 87-108.

Cassirer, E. (1955). The Philosophy of Symbolic Forms. Yale: Yale University Press.

Castoriadis, C. (1997). The Imaginary Institution of Society. Cambridge: MIT Press.

Coca, J. R. (2008). Las posibilidades del Imaginario. Barcelona: Serbal.

Coca, J. R. y Valero, J. A. (2012). Socio-Hermenéutica Pluri-Analógica e Imaginarios Sociales en el contexto de la actividad tecnocientífica. Bogotá: RIPS. Revista de Investigaciones Políticas y Sociológicas, 12(2), 127-43.

Corbin, H. (1993). La imaginación creadora en el Sufismo de Ibn'Arabi. Barcelona: Destino.

Durand, G. (1999). Anthropological structures of the imaginary. Charlottesville: Boombana Publications, University of Virginia.

Durand, G. (1962). Les Structures anthropologiques de l'imaginaire: Introduction à l'archétypologie générale. París: PUF.

Durkheim, E. (1965). The Elementary Forms of Religious Life. A Study in Religious Sociology. Washington: Free Press.

Eliade, M. (1963). Aspects du Mythe. París: Gallimard.

Fleury, C. (2006). Imagination, Imaginaire, Imaginal. París: PUF. 
Foucault, M. (1970). The Order of Things. Londres : Routledge.

Girola, L. (2007). Modernización, Modernidad y Después. Las Ciencias Sociales En América Latina y la construcción de los Imaginarios de la Modernidad. Modernidades: narrativas, mitos e imaginarios. Barcelona: Anthropos, 61-104.

Günter, G. (1979). Life as Poly-Contexturality. Beiträge zur Grundlegung einer operationsfähiger Dialektik II.

Jung, C. (1991). Arquetipos e Inconsciente Colectivo. Buenos Aires: Paidós.

Kuhn, Th. (2012). The Structure of Scientific Revolutions. Chicago: University of Chicago Press.

Lacan, J. (1997). Seminars of Jacques Lacan. Nueva York: WW Norton \& Company.

Lévi-Strauss, Cl. (2008). Structural Anthropology. Nueva York: Basic Books.

Luhmann, N. (2010). Love: A Sketch. Cambridge: Polity Press.

Luhmann, N. (1986). Love as Passion: The Codification of Intimacy. Cambridge: Polity Press.

Luhmann, N. (2012). Theory of Society. Stanford: Stanford University Press.

Maffesoli, M. (1985). La Connaissance Ordinaire : Précis de Sociologie Compréhensive. París : Klincksieck.

Maffesoli, M. (1995). The Time of the Tribes: The Decline of Individualism in Mass Society. Thousand Oaks: Sage.

Marx, K. y Engels, F. (2009). The Economic and Philosophic Manuscripts of 1844 and the Communist Manifesto. Amherst: Prometheus Books.

Moeller, H.-G. (2005). Luhmann Explained: From Souls to Systems. Illinois: Open Court Publishing.

Moeller, H.-G. (2013). The Radical Luhmann. Nueva York: Columbia University Press.

Morin, E. (1992). El Método IV: Las Ideas. Su Hábitat, Su Vida, Sus Construmbres, Su Organización. Madrid: Cátedra.

Ortega y Gasset, J. (1986). Ideas y Creencias (y otros ensayos de Filosofía)(Ideas and Beliefs (and other Philosophical essays). Madrid: Editorial Alianza/Revista de Occidente.

Pessin, A. (2001). L'imaginaire Utopique Aujourd'hui. París : Presses universitaires de France.

Pintos, J. L. (1995). Los Imaginarios Sociales: La nueva construcción de la realidad social. Bilbao: Sal Terrae.

Pintos, J. L. (2018). Imaginarios Sociales: Construcción de la realidad y política de las cosas. Bogotá: RIPS. 
Pintos, J. L., Marticorena, J.R. y Rey, R. (2004). El rol del paciente en Salud Mental. Memoria de investigación.

Pintos, J. L., and Marticorena, J. R. (2012). Análisis Sociocibernético del discurso. La explotación de datos y los procedimientos informatizados en las investigaciones sobre Imaginarios Sociales. Un Caso. Bogotá: Revista de Investigaciones Políticas y Sociológicas, 11(2).

Sansot, P. (1986). Les formes sensibles de la vie sociale. París : PUF.

Tacussel, P. (2000). La sociologie interprétative. Un tournant postempiriste dans les sciences humaines en France. París : La Sociologie française contemporaine.

Taylor, Ch. (2004). Modern Social Imaginaries. Durham : Duke University Press.

Thomas, J. (1998). Introduction Aux Méthodologies de l'imaginaire. París: Ellipses.

Torres Cubeiro, M. (2012). Imaginarios Sociales de La Enfermedad Mental. Bogotá: RIPS, 11(2), 101-14.

Torres Cubeiro, M. (2015). La evolución del concepto de Imaginarios Sociales en la obra publicada de Juan Luis Pintos de Cea Naharro. Vigo: Imagonautas, 6, 114.

Torres Cubeiro, M. (2009). Marcando unha Diferenza: Scripts, Imaxinarios Sociais e Enfermidade Mental grave en Galicia. Madrid: Sociologías de los márgenes: Libro homenaje a Juan Luis Pintos de Cea-Naharro, 1000-1023.

Torres Cubeiro, M. (2013). Niklas Luhmann. Coruña: Baía. 